\title{
Paleomagnetism of the Late Archean Nyanzian System, western Kenya
}

\author{
Joseph G. Meert ${ }^{\mathrm{a}, *}$, Rob Van der Voo ${ }^{\mathrm{a}}$, Jay Patel \\ ${ }^{a}$ University of Michigan, Department of Geological Sciences, 1006, C.C. Little Bldg., Ann Arbor, MI 48109-1063, USA \\ ${ }^{b}$ University of Nairobi, Nairobi, Kenya
}

Received December, 1991; revised version accepted August, 1992

\begin{abstract}
The Nyanzian System lavas of western Kenya are believed to be the oldest rocks of the Tanzanian Craton. Intrusive age relationships suggest an age $\geqslant 2850 \mathrm{Ma}$ although direct attempts at dating the Nyanzian have produced disparate results. Our study involves a suite of samples collected from the Nyanzian basalts, pillow basalts, andesites and rhyolites from sixteen sites in western Kenya. These rocks yield a tilt-corrected paleomagnetic pole at $14^{\circ} \mathrm{N}, 150^{\circ} \mathrm{E}\left(K=59, \mathrm{dp}=5^{\circ}, \mathrm{dm}=7^{\circ}\right)$. This pole is constrained to be older than the first (D1) deformation $(>2472 \pm 30 \mathrm{Ma}$ ) by positive fold, conglomerate and reversal tests. Analysis of the paleomagnetic data base for three African cratonic nuclei (Tanzanian, Kaapvaal/Zimbabwe and West Africa) for the time period from $2.0 \mathrm{Ga}$ to $3.0 \mathrm{Ga}$ demonstrates a paucity of well-dated poles, although there are several poles from the Kaapvaal/Zimbabwe and Tanzanian Cratons which allow "spot-readings" of their relative positions. We demonstrate, based on these data, that the Kaapvaal/Zimbabwe and Tanzanian Cratons were drifting independently at $\sim 2875 \mathrm{Ma}, \sim 2700$ $\mathrm{Ma}$ and $\sim 2450 \mathrm{Ma}$. This independent motion of the Tanzanian and Kaapvaal/Zimbabwe Cratons indicates that previously proposed models involving African cratonic coherence can no longer be considered valid for the time period from 2850 to $2500 \mathrm{Ma}$.
\end{abstract}

\section{Introduction}

One of the salient problems in modern geology remains the characterization of Archean and $\mathrm{Pa}$ leoproterozoic tectonics. The nature and style of tectonism during the Earth's infancy may one day be elucidated by a set of high-quality paleomagnetic data. Defining Archean-Paleoproterozoic apparent polar wander paths is difficult given the paucity of data from different continents; how-

\footnotetext{
* Present address: Department of Geography and Geology, Indiana State University, Terre Haute, IN 47809, USA, Fax 812-237-8029.
}

ever, recent works by Symons (1991) and Hale (1991) have demonstrated the efficacy of approaching the problem on a smaller scale (i.e. motions between individual nuclei). In addition, questions regarding the exact nature of the Earth's early magnetic field may be revealed through paleomagnetic investigations (e.g. nature of reversals). In this paper, we (1) report on an investigation of the Nyanzian System of western Kenya and (2) analyze previously published paleomagnetic data from three African cratonic nuclei (Fig. 1a, Tanzanian, Kaapvaal/ Zimbabwe and West Africa).

The Tanzanian Craton of East Africa is com- 

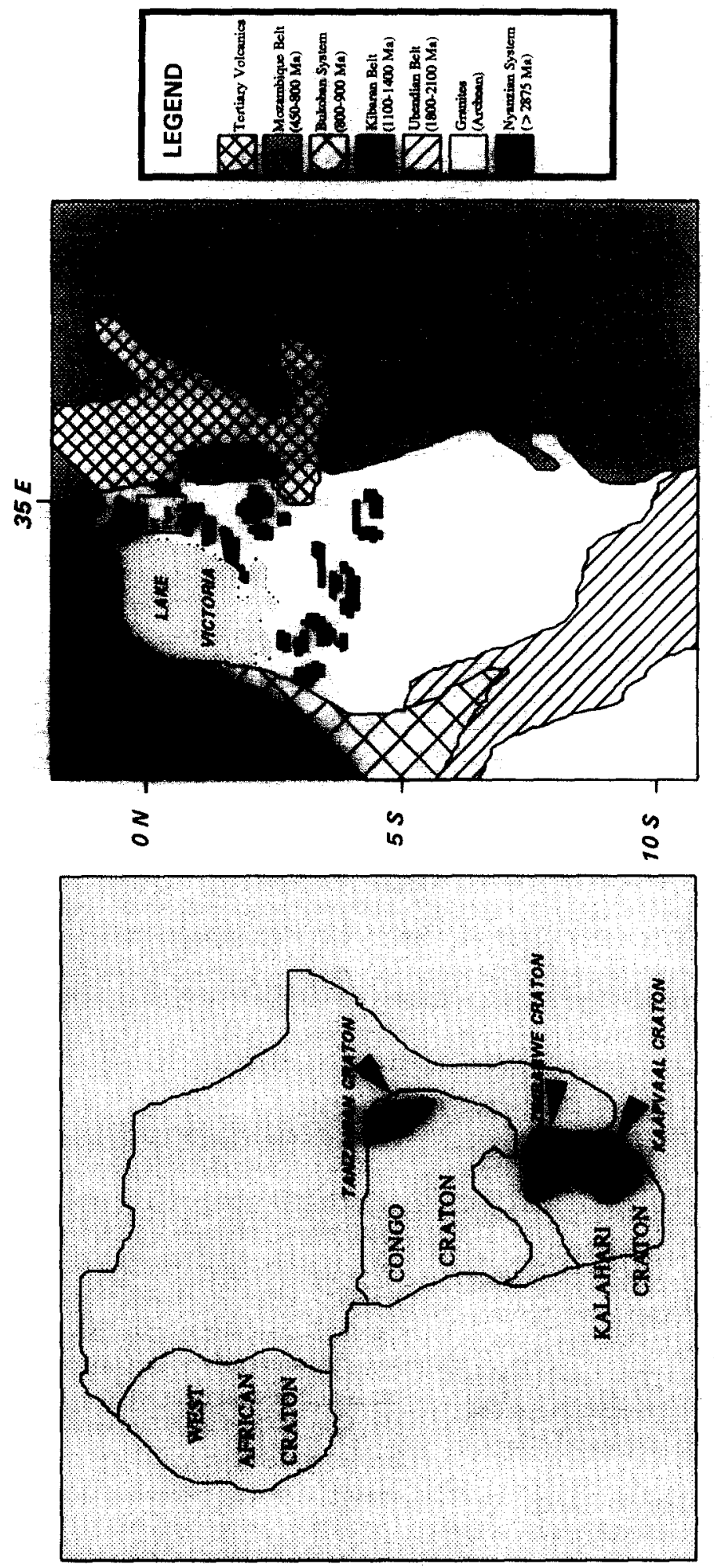

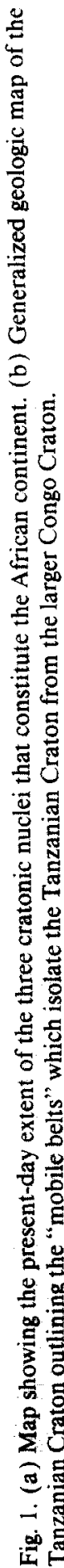


posed principally of Archean-age rocks surrounded by a series of Proterozoic-age "mobile belts". These mobile belts are: the Mozambique Belt to the east (500-800 Ma), the Ubendian Belt to the south-southwest (1800-2100 Ma), and the Kibaran Belt to the west-northwest (1100-1400 Ma). These belts effectively isolate the Tanzanian Craton from other Archean nuclei that constitute the larger Congo Craton (Fig. 1b). The Tanzanian Craton is composed of granitic rocks, schist belts, greenstone belts and younger cover rocks. The two oldest units are the Dodoman System of Tanzania (Quennell, 1956) and the Nyanzian System of Kenya, Tanzania and Uganda. The Dodoman System has not been clearly defined because only a single $\mathrm{Rb}-\mathrm{Sr}$ whole-rock age of $2573 \pm 34 \mathrm{Ma}$ (Wendt et al., 1972 ) on an orthogneiss is available. Cahen et al. (1984) considered this age to represent a younger limit to the Dodoman metamorphism. The Nyanzian System consists of a succession composed of, from top to bottom: a greywacke and andesitic volcanic group with abundant banded iron formations; an intermediate group composed of rhyolites with intercalated tuffs and agglomerates and a basal unit composed of mafic volcanic rocks (pillow lavas and flows) with some (rare) banded ironstones (Shackleton, 1946). The total thickness of the Nyanzian System has been estimated at $7500 \mathrm{~m}$ (Grantham, 1945).

The Kavirondian System unconformably overlies the Nyanzian rocks and is composed of pelitic rocks, arkoses and conglomerates. Neither the Kavirondian nor the Nyanzian Systems are well-dated; in fact, the published ages for the Nyanzian rocks were reported by Yanagi and Suwa (1981) as $2710 \pm 340 \mathrm{Ma}$ (Rb-Sr whole rock) and $2380 \pm 250 \mathrm{Ma}$ (Rb-Sr, Bell and Dodson, 1981). These ages only roughly overlap and the large errors associated with the ages suggest that neither can be considered reliable. The ages of these two systems are better bracketed by ages of granitic intrusions into these units. Definite post-Kavirondian granites yield ages of $2472 \pm 30$ $\mathrm{Ma}$ ( $\mathrm{Rb}-\mathrm{Sr}$ whole-rock ages from the Mumias granite of Kenya and the Buteba granite of Uganda by Cahen et al. (1984) and 2420 \pm 60
Ma (Wanjare granite, Yanagi and Suwa, 1981). Dodson et al. (1975) obtained a whole-rock isochron ( $\mathrm{Rb}-\mathrm{Sr}$ ) for the Migori granite (Kenya) that yielded an age of $2739 \pm 111 \mathrm{Ma}$. The Migori granite intrudes the Nyanzian System but does not intrude the Kavirondian thus bracketing the age of the Kavirondian between $\sim 2450$ and $\sim 2750 \mathrm{Ma}$. Despite this, Ichang'i and MacLean (1991) place the age of the Nyanzian System between 2800 and as young as $2600 \mathrm{Ma}$. In contrast, Cahen et al. (1984) interpreted all the ages as indicating a $\sim 2850$ Ma younger limit for the Nyanzian System. Coomer and Robertson (1974) published $\mathrm{Pb}-\mathrm{Pb}$ ages on sulfides produced during gold mineralization in the Nyanzian greenstones, giving an age of $2700 \pm 150 \mathrm{Ma}$. This age is broadly coeval with the age determination on the Migori granite. We take the estimate of Cahen et al. (1984) for the lower limit of the age for the Nyanzian System as the most appropriate. Several authors noted the age disparity between the Nyanzian greenstone belt and the older ( $>3.3 \mathrm{Ga}$ ) greenstone belts of the Kaapvaal/Zimbabwe Craton (Dodson et al., 1975; Davis and Condie, 1977; Cahen et al., 1984).

\section{Structural and metamorphic history}

Saggerson (1952) and Huddleston (1951) agreed with previous workers (e.g. Pulfrey, 1945) that the Nyanzian System of western Kenya experienced two episodes of folding. The first episode (D1) was post-Nyanzian ( $<2850 \mathrm{Ma})$ and pre-Kavirondian ( $>2472 \mathrm{Ma}$ ) and the second episode (D2) of folding is post-Kavirondian but older than post-Kavirondian granites and thus also $>2472 \mathrm{Ma}$. In the northern Kisumu district (Fig. 2A) the D1 episode is dominated by steeply dipping limbs $\left(>50^{\circ}\right)$ and NE-SW strikes. This D1 folding episode is more complex in the southern Kisumu and Kisii districts (Figs. 2A, 2B) where the limb dips remain steep but strikes are more likely to trend NW-SE. The D2 created more open folds (dips of limbs typically $30^{\circ}-$ $40^{\circ}$ ) with E-W trending fold axes. Penetrative deformation (shearing) is prominent near the contacts of granitic intrusions but is absent else- 
where in the Nyanzian and Kavirondian rocks (Huddleston, 1951).

The Nyanzian System has been affected by lowgrade metamorphism typical of greenstone belts (i.e. greenschist and lower) except near contacts with granitic or doleritic intrusions where the grade is higher. In these cases, the thermal aureole extends only a short distance beyond the intrusive contact (Huddleston, 1951; Saggerson, 1952; Ichang'i and MacLean, 1991). Higher grades of metamorphism are also observed in rocks near the boundary with the Pan-Africanage Mozambique Belt (Sanders, 1965).

\section{Paleomagnetism of the Nyanxian System}

A total of 111 samples were collected from 16 sites in western Kenya (Nyanzian rhyolites, basalts, pillow basalts and andesites). Most samples were drilled in the field using a conventional gasoline-powered drill with the exception of Site 16 where specimens were drilled in the laboratory from oriented hand samples. Drilled samples were oriented using magnetic compass and inclinometer with sample intensities too low to influence compass readings. Outcrop locations in western Kenya are limited due to intense weathering; however, suitable outcrops with variable bedding corrections were found in roadcuts, mines and quarries (for sites and bedding orientation see Figs. 2A, 2B). A total of sixteen samples of Nyanzian clasts were collected from a Kavirondian conglomerate at Site 7 for a conglomerate test.

The intensities of the natural remanent magnetization (NRM) range between $10^{-4}$ and $1 \mathrm{~A} /$ $\mathrm{m}$ as measured on either an ScT cryogenic magnetometer or a Schonstedt spinner magnetometer. Thermal and alternating field (AF) demagnetization carried out on a pilot selection of samples proved to be of equal value and yielded

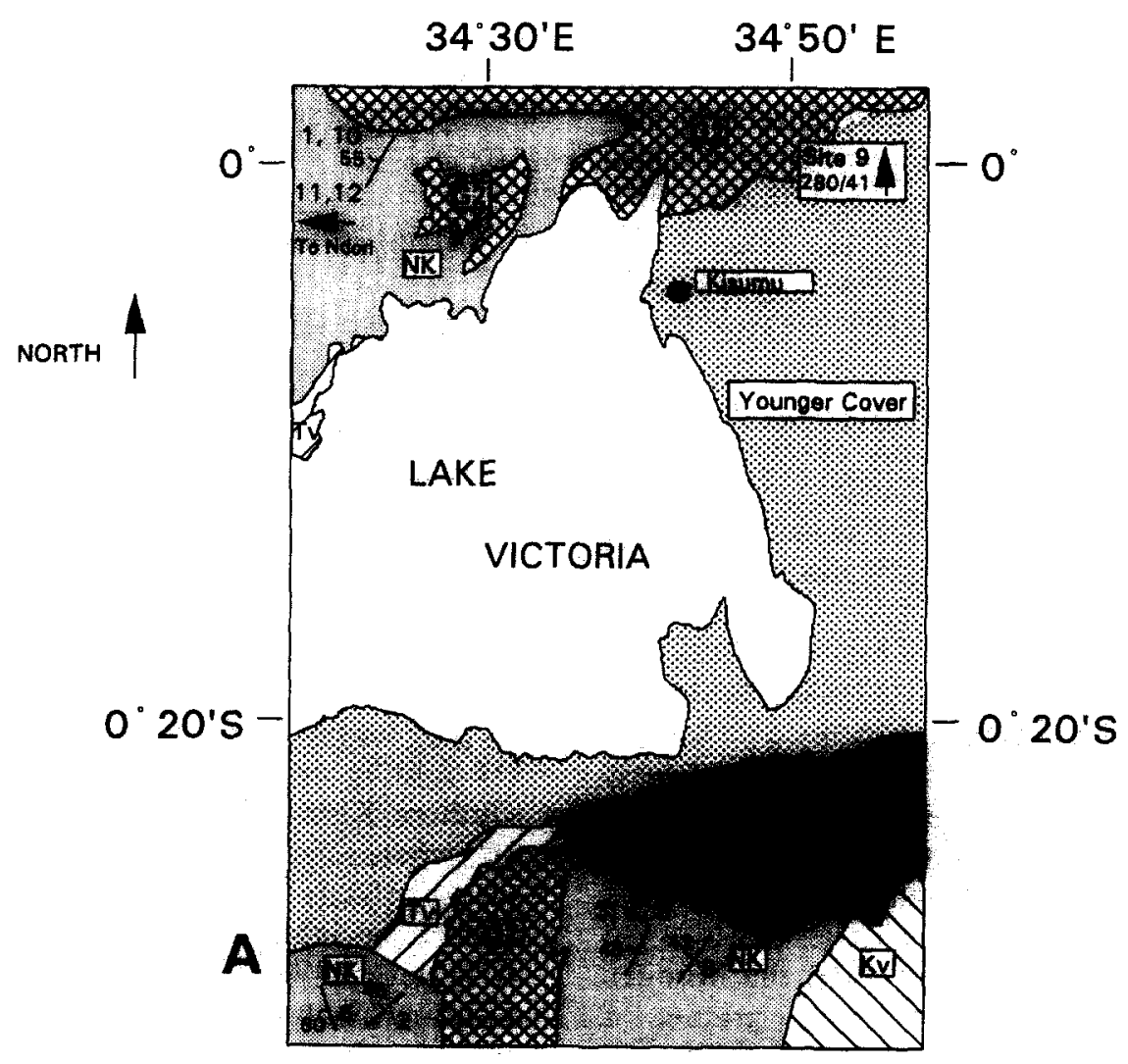




\section{LEGEND}
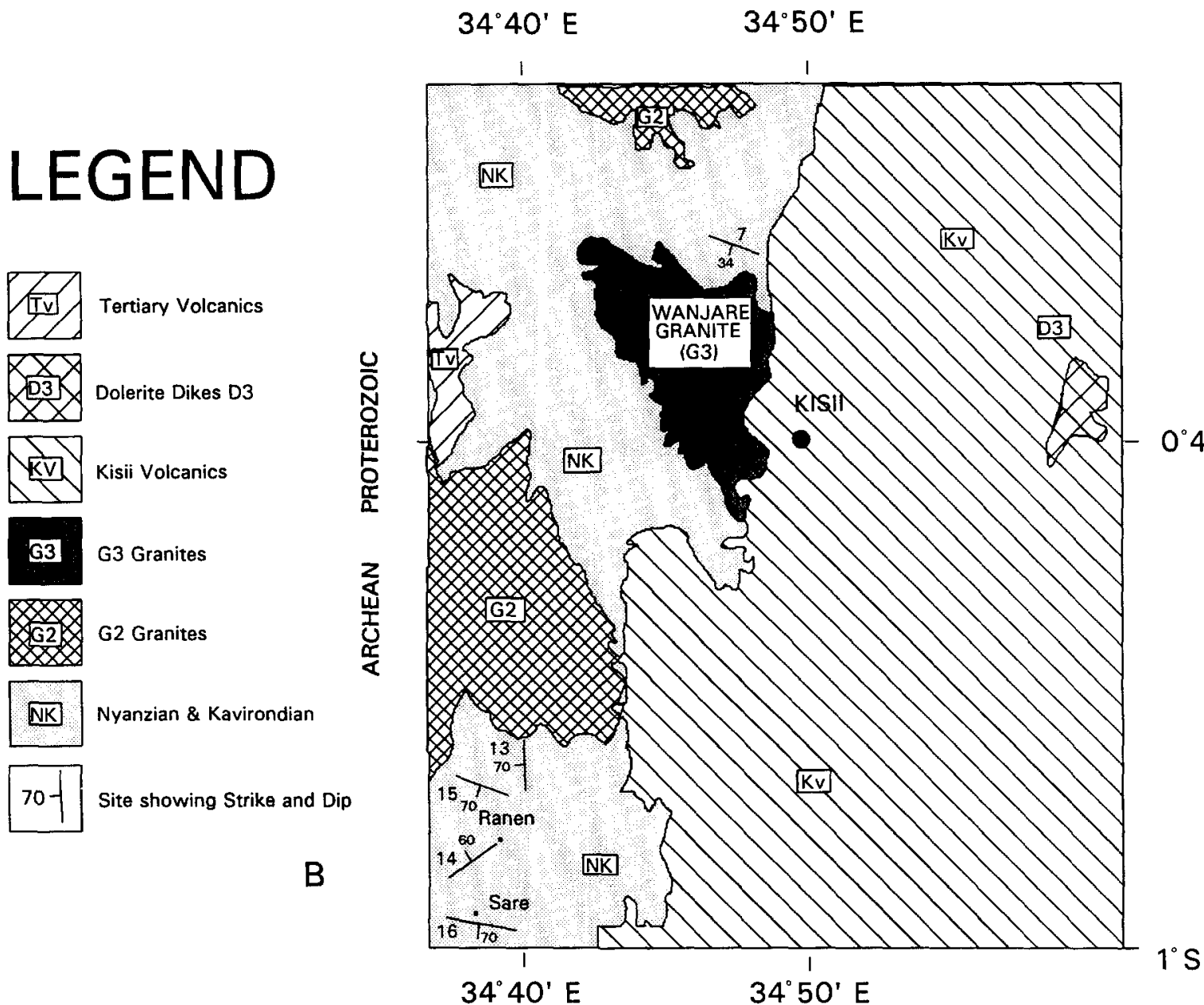

Fig. 2. (A) Geologic sketch map of the Kisumu district (W Kenya) showing locations of paleomagnetic sampling sites and bedding orientation. Modified from Saggerson, 1952. (Sites 1,10,11 and 12 fall outside published geologic maps and these are located approximately $15 \mathrm{~km}$ west of the location shown). Site 9 is located near the contact with the Mozambique Belt (approximately $25 \mathrm{~km}$ north of the location shown on map). (B) Geologic sketch map of the Kisii district (W Kenya) showing paleomagnetic sampling sites and bedding orientations. Modified from Huddleston, 1949.

similar results; nevertheless, most samples were treated thermally because complete decay of the NRM could be achieved. Demagnetization results were plotted in orthogonal vector diagrams (Zijderveld, 1967), and linear trajectories were used to determine directions of magnetic components, through principal component analysis comprising generally three measurements or more (Kirschvink, 1980). The orthogonal vector plots typically revealed a single-component magnetization with a very narrow unblocking range between $550^{\circ}$ and $590^{\circ} \mathrm{C}$ or coercivities greater than $100 \mathrm{mT}$ (Figs. 3 and 4 ). In all cases the characteristic direction was isolated by $500^{\circ} \mathrm{C}$ and the NRM has decayed linearly to the origin by $590^{\circ} \mathrm{C}$ suggesting that single-domain magnetite is the carrier of the remanence. Isothermal remanence acquisition (IRM) studies show saturation of samples by 0.3 tesla $(\mathrm{T})$ typical of magnetite (Fig. 5b). In addition, the AF coercivity of a $0.1 \mathrm{~T}$ anhysteretic remanent magnetization (ARM) is stronger than the AF coercivity 

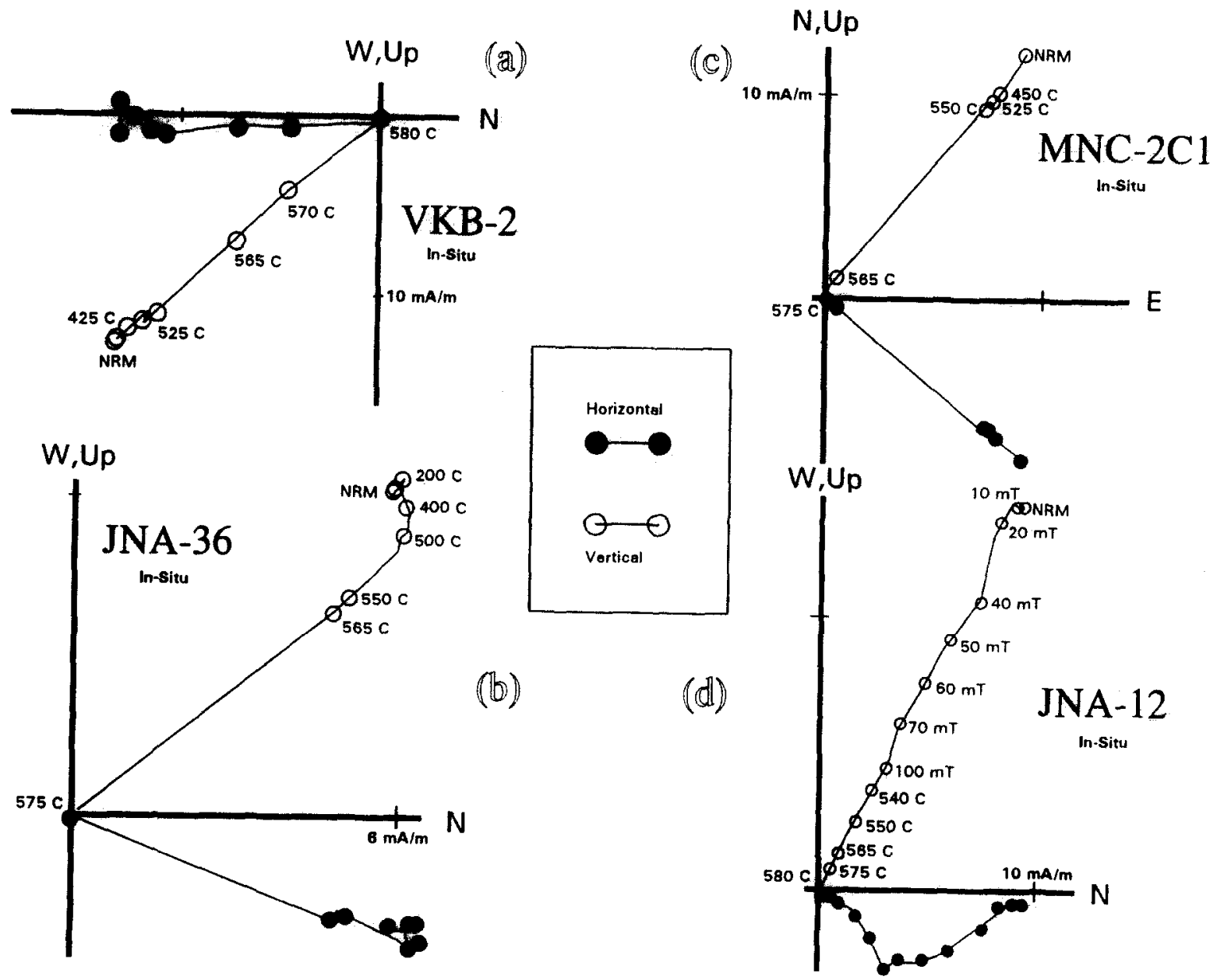

Fig. 3. (a) Typical orthogonal vector plot (in-situ) of a Nyanzian basalt sample showing the near univectorial decay of the NRM (Site 10). (b) Orthogonal vector plot (in-situ) of a Nyanzian rhyolite sample showing a very small (random) overprint and linear decay of the NRM (Site 8). (c) Orthogonal vector plot (in-situ) of a Nyanzian andesite sample showing univectorial decay of the NRM (Site 15). (d) Combined AF and thermal orthogonal vector plot (in-situ) of a rhyolite sample demonstrating the incomplete decay of the NRM using peak AF field of $100 \mathrm{mT}$.

of a 0.1 T IRM (Fig. 5c) indicative of single-domain (or pseudo single-domain) grains (Johnson et al., 1975). Several samples, usually those with weaker NRM intensities, show two components of magnetization (Fig. 4b). The lower temperature component is removed by $300^{\circ} \mathrm{C}$; the in-situ directions generally correspond to the local present-day magnetic field direction, and are thus likely to be a viscous overprint of recent origin. A number of samples showed a very soft component of magnetization removed by $400^{\circ} \mathrm{C}$, that is random, and no coherent signal above $400^{\circ} \mathrm{C}$ (Figs. $6 \mathrm{a}, 6 \mathrm{~b}$ ). Samples that displayed this type of behavior were found (a) near contacts with granitic bodies (Site 12), or (b) near the contact with the Mozambique Belt (Site 9) and these sites were rejected. One site (Site 16) showed univectorial decay similar to that of typical Nyanzian materials; however, the within-site grouping was random at the $95 \%$ confidence level (using the criteria of Irving, 1964) and the site mean was rejected from the overall analysis (Fig. 6c). Orthogonal vector plots of Site-13 samples (sheared rhyolites) show a univectorial decay 

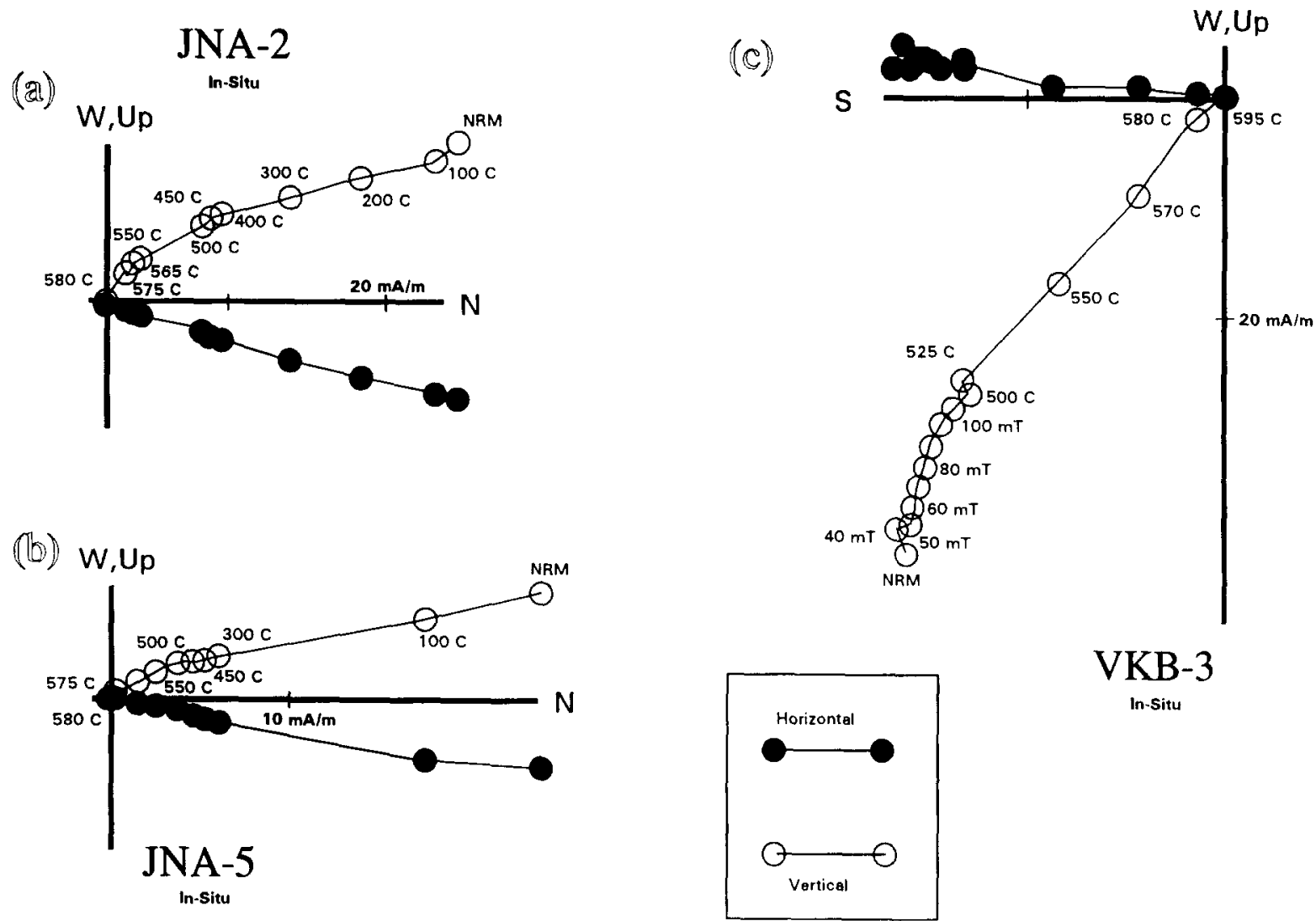

Fig. 4. (a), (b) Orthogonal vector plots (in-situ) of Nyanzian rhyolite samples from Site 5 showing two-component magnetizations, the first removed representing a contaminated present-day field overprint. (c) Combined AF and thermal orthogonal vector plot (in-situ) of a Nyanzian basalt sample (Site 1) showing incomplete decay of the NRM using peak AF field of 100 $\mathrm{mT}$.

towards the origin and an excellent within-site grouping; however, neither the in-situ nor the tiltcorrected directions correspond to the characteristic direction seen in the well-grouped Nyanzian sites and this site was also rejected from the mean (Fig. 6d).

The characteristic directions isolated in eleven of the sixteen sites (68/95 samples) reveal both polarities: either $D=9^{\circ}, I=-64^{\circ}$ or $D=195^{\circ}$, $I=+51^{\circ}$ (in-situ) and $D=72^{\circ}, I=-46^{\circ}$ or $D=257^{\circ}, I=+39^{\circ}$ (tilt-corrected). The combined in-situ mean is calculated at $D=15^{\circ}$, $I=-61^{\circ}\left(k=11, \alpha_{95}=15^{\circ}\right)$ and the tilt-corrected mean $D=74^{\circ}, \quad I=-43^{\circ} \quad(k=46$, $\left.\alpha_{95}=6^{\circ}\right)$. The mean of the directions shows an increase in the Fisher precision parameter $k$
(Fisher, 1953) and a decrease in the $\alpha_{95}$ angle after tilt-correction indicating that the characteristic remanence was acquired prior to folding (Table 1; Fig. 7). The fold test is significant at the $95 \%$ confidence level according to McElhinny (1964), and the McFadden (1990) fold test statistic $\xi$ demonstrates that the hypothesis which assumes that the magnetization was acquired in-situ can be rejected at the $99 \%$ confidence level. This positive fold test does rely heavily on the results from Sites 6 and 15, which have dips in opposite directions from those of the other sites which all have similar bedding corrections (Table 1). Still, we have no a priori reason to reject these two sites and can thus consider the magnetization to be pre-folding. 

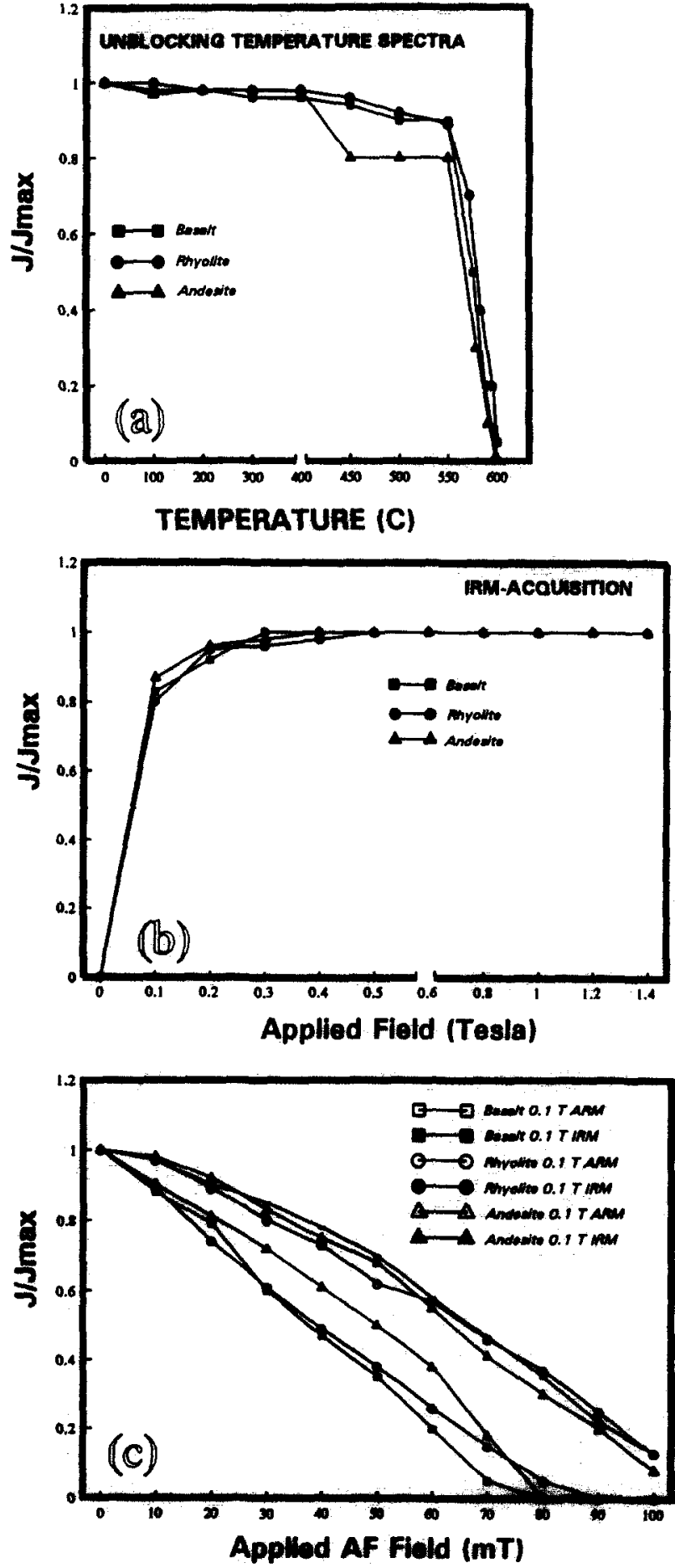

Clasts of Nyanzian materials found in the Kavirondian conglomerate show similar demagnetization behavior to parent materials as well as similar NRM intensities. Samples that show two components have a soft component that is removed by $500^{\circ} \mathrm{C}$ or $40 \mathrm{mT}$ that yields an in-situ mean $D=349^{\circ}, I=-1^{\circ}\left(k=5, \alpha_{95}=24^{\circ}\right)$ corresponding to the local present-day field direction for this site. The mean direction for the higher unblocking temperature component from these clasts yields an in-situ direction of $D=259^{\circ}, I=+39^{\circ}\left(k=1.4, \alpha_{95}=58^{\circ}, R=5.13\right.$; see Table 1 and Fig. 8). The in-situ direction for these clasts is random at the $95 \%$ confidence level using the Irving (1964) criterion $\left(R_{95}=6.40\right.$ for $n=16$ ), yielding a positive conglomerate test. These results demonstrate that the magnetization of the Nyanzian rocks is pre-Kavirondian (>2450 Ma).

McFadden and McElhinny (1990) have proposed a revised reversal test. Assuming that the normal polarity mean direction for the Nyanzian rocks is $D=9^{\circ}, I=-64^{\circ}$ (in-situ) and the reverse polarity mean is $D=195^{\circ}, I=+51^{\circ}$ (insitu ), the reversal test for these means is inconclusive. The tilt-corrected normal polarity mean direction is $D=72^{\circ}, I=-46^{\circ}$ ( $k$-normal $=55$ ) and the reverse polarity mean is $D=257^{\circ}$, $I=+39^{\circ}(k$-reverse $=65)$. The tilt-corrected directions pass the common kappa test and the angle between the normal and reverse directions is $7^{\circ}$ (the critical angle $\gamma_{c}=12.2^{\circ}$ ). This results in a positive reversal classification of $R_{\mathrm{c}}$.

The mean directions of each site, their associated statistical parameters, and the calculated pole positions are given in Table 1 along with the grand mean of all sites and the resultant paleopole. The calculated paleopole for the Nyanzian System is $14^{\circ} \mathrm{N}, 150^{\circ} \mathrm{E}\left(n=11, K=56, \mathrm{~A}_{95}=6^{\circ}\right.$, $\mathrm{dp}=5^{\circ}, \mathrm{dm}=7^{\circ}$, tilt-corrected $)$. The age of this

Fig. 5. (a) Unblocking temperature curves for typical samples of Nyanzian basalt, thyolite and andesite samples. (b) Isothermal Remanence Acquisition (IRM) curves for typical samples of Nyanzian basalt, rhyolite and andesite samples. (c) Response of typical Nyanzian materials with IRM $(0.1 \mathrm{~T})$ and $A R M(0.1 \mathrm{~T})$ to $A F$ demagnetization indicating single to pseudo-single domain magnetic carriers. 


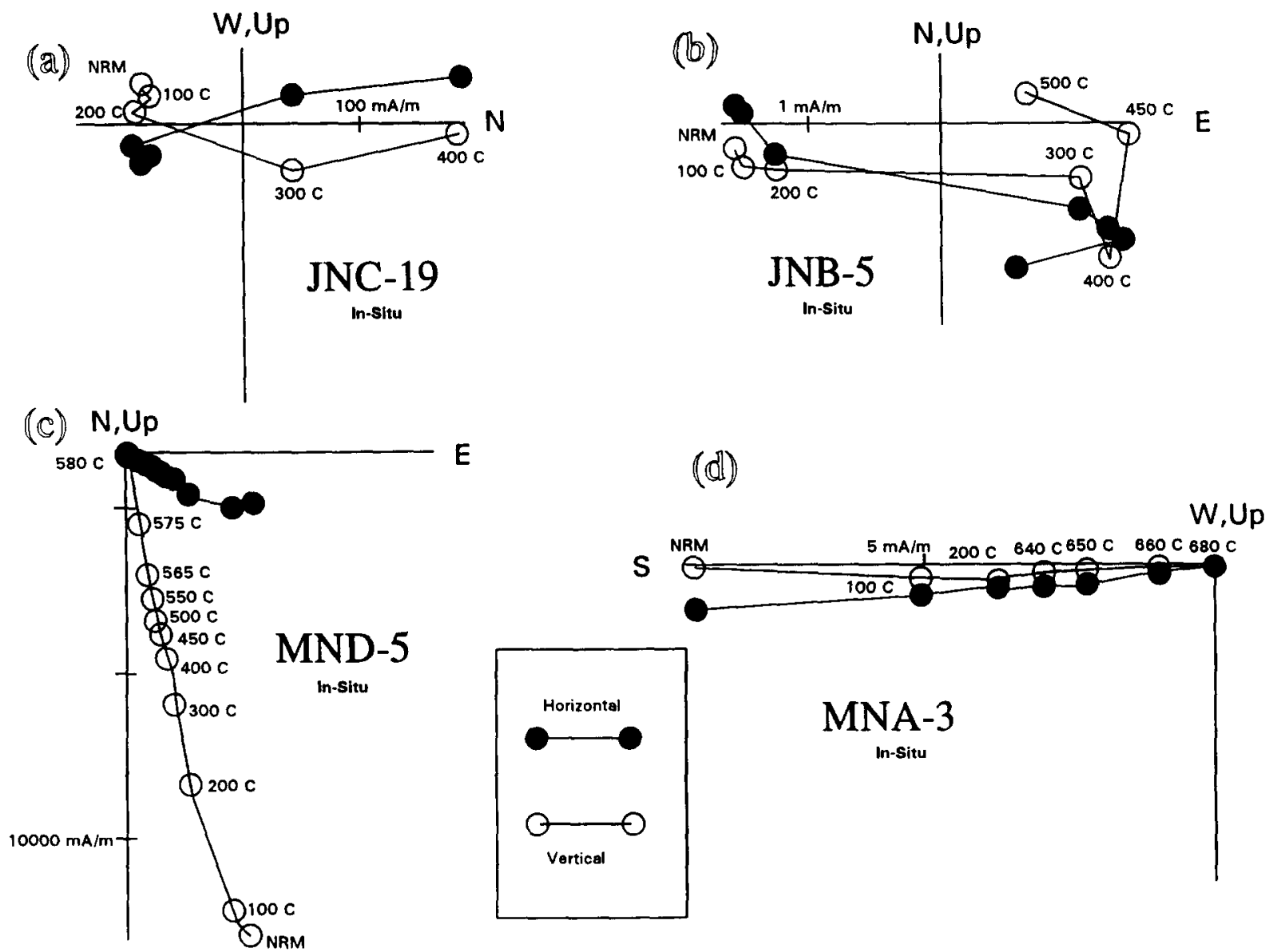

Fig. 6. Orthogonal vector plots (in-situ) of selected samples rejected in this study. (a) Basalt near granite-pegmatite contact at Site 12. (b) Andesite sample near the contact with Mozambique metamorphic belt at Site 9. (c) Andesite sample showing near univectorial decay but random, within-site grouping at Site 16. (d) Sheared rhyolite sample showing univectorial decay of a hematite-carried remanence at Site 13.

paleopole is at least older than the deformation of the Nyanzian System (i.e. older than $2472 \pm 30$ $\mathrm{Ma}$ ) as constrained by the positive fold and conglomerate tests.

\section{Interpretation of results}

With the exception of the Cunene anorthosite pole (Angola, Piper, 1974), all paleomagnetic results for the Congo Craton in the time period from 2000 to $3000 \mathrm{Ma}$ are derived from units in the Tanzanian Craton. The most likely age for the "welding" of the Zambia and Tanzania nu- clei to the Angola, Kasai and Gabon-Congo nuclei of west Congo is a Kibaran-age event ( $1300 \mathrm{Ma}$; Clifford, 1971; Rumvegeri, 1991), and it is therefore preferable to treat the Tanzanian Craton as a separate block. One of the poles from the Tanzanian Craton, the Oldoinyo gneiss pole (Mauritsch and Pondaga, 1985), is poorly dated and based on only five samples from one site $(Q=1)$. Therefore, the Oldoinyo Gneiss pole will not be used in the analysis below.

The Mumias granite $(2472 \pm 30 \mathrm{Ma}$, Dodson et al., 1975, recalculated using $\mathrm{Rb}-\mathrm{Sr}$ decay constant of $1.42 \times 10^{-11}$ by Cahen et al., 1984) and the post-Kavirondian granites $(2420 \pm 60 \mathrm{Ma}$, 
Table I

Paleomagnetic results

\begin{tabular}{|c|c|c|c|c|c|c|c|c|c|c|}
\hline \multirow[t]{2}{*}{ Silc } & \multirow[t]{2}{*}{ Lithology } & \multirow[t]{2}{*}{ Strike/dip } & \multirow[t]{2}{*}{$n / N$} & \multicolumn{2}{|c|}{ In-situ } & \multicolumn{2}{|c|}{ Till-corrected } & \multirow[t]{2}{*}{$k$} & \multirow[t]{2}{*}{$x_{y, s}$} & \multirow[t]{2}{*}{$\mathrm{VGP}$} \\
\hline & & & & i) & $i$ & b) & $i$ & & & \\
\hline 1 & Basalt & $210 / 55$ & $\%$ & 181 & +52 & 253 & +44 & 88 & 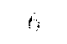 & $159.3 \mathrm{t}$ \\
\hline 2 & Rhyolite & $225 / 45$ & $6 / 6$ & 013 & -46 & 068 & -50 & 31 & $1:$ & $19 \mathrm{~N}: \mathrm{O}$ \\
\hline 3 & Rhyolite & $210 / 43$ & $4 / 4$ & 003 & -.54 & 073 & -44 & 427 & $\because$ & $15 \mathrm{~N} .15 \mathrm{H}$ \\
\hline 4 & Rhyolite & $212 / 50$ & $9 / 10$ & 358 & -.57 & 077 & -51 & 172 & 4 & $11 N, 1$ \\
\hline 5 & Rhyolite & $195 / 46$ & $5: 5$ & 356 & -64 & 068 & -47 & 82 & 3 & $11 \% 191$ \\
\hline 6 & Rhyolite & $160 / 60$ & $6 / 6$ & 230 & $\ldots 74$ & 077 & -45 & 179 & 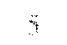 & $12 \mathrm{~N} ; \mathrm{F}$ \\
\hline$\gamma$ & Conglomerate & $110 / 34$ & $16 / 16$ & 259 & +391 & $\ldots$ & .. & $i$ & 38 & Cong. 45 \\
\hline 8 & Rhyolite & $230 / 42$ & $5 / 6$ & 010 & 52 & 076 & -58 & 30 & 14 & $11 \mathrm{~N}, 164: 2$ \\
\hline 9 & Andesite & $280 / 41$ & $8 / 8$ & & $\ldots$ & -. & - & - & & See 1ex: \\
\hline 10 & Basalt & $210 / 55$ & $7 \%$ & 193 & +53 & 253 & +37 & 24 & 12 & $16 \mathrm{~S}, 320 \mathrm{I}$ \\
\hline 11 & Basalt & $210 / 53$ & 56 & 204 & +51 & 253 & +29 & 49 & 10 & $16^{\circ} \mathrm{S}, 32 \mathrm{E}$ \\
\hline 12 & Metabasalt & $210 / 53$ & $0 / 5$ & & - & $\ldots$ & $\ldots$ & & & See tex: \\
\hline 13 & Sheared rhyolite & $178 / 70$ & $3 / 5$ & $(182$ & $+08)$ & 180 & $+04 j$ & 16 & 14 & See tex? \\
\hline 14 & Basalt & $235 / 60$ & $4 / 5$ & 200 & +47 & 271 & +45 & 10 & 30 & $00 \mathrm{~N}, 3 \rightarrow \mathrm{E}$ \\
\hline 15 & Andesite & $110 / 70$ & $10 / 10$ & 122 & $\ldots 44$ & 069 & -24 & 56 & 7 & $21^{\circ} \mathrm{N} / \mathrm{XP}$ \\
\hline 16 & Andesite & $100 / 70$ & $5: 5$ & 1097 & $+33)$ & $(133$ & $+13)$ & 2 & 2 & Seetext \\
\hline \multicolumn{3}{|c|}{ Site means (in-situ) } & $N=11 / 16$ & 015 & -61 & & & 11 & 15 & $66 \mathrm{~N}, 2 \% \mathrm{l}$ \\
\hline \multicolumn{3}{|c|}{ Site means (tilt-corrected) } & $N=11 / 16$ & & & 074 & -43 & 56 & $b$ & $14 \mathrm{~N}, 150 \mathrm{~F}$ \\
\hline
\end{tabular}

Notes. Directions in parentheses have not been included in the overall mean directions. Strike convention uses left-hand rule. $h t$ $N=$ number of samples used $/$ samples in site; $D=$ declination in degrees; $I=$ inclination in degrees; $k=$ Fisher precision parameter: $\alpha_{95}=95 \%$ confidence cone; $\mathrm{VGP}=$ virtual geomagnet ic pole.

Yanagi and Suwa, 1981, Wanjare granite) yield paleomagnetic poles which are not significantly different from each other (Patel, 1989). These poles $\left(41^{\circ} \mathrm{N}, 263^{\circ} \mathrm{E}\right.$ post-Kavirondian pole; $61^{\circ} \mathrm{N}, 211^{\circ} \mathrm{E}$ Mumias pole) are both post-Kavirondian in age. Patel (1989) also noted that of the three "post-Kavirondian" granites he sampled (Wanjare, Kitere and Kilgoris), only the Wanjare granite has been directly dated and that perhaps the Kitere and Kilgoris granites may be of different ages. Indeed, the Wanjare granite virtual geomagnetic pole $\left(60^{\circ} \mathrm{N}, 246^{\circ} \mathrm{E}\right.$, $\mathrm{dp}=13^{\circ}, \mathrm{dm}=20^{\circ}$ ) lies much closer to the $\mathrm{Mu}$ mias pole (Patel and Raja, 1979) at $61^{\circ} \mathrm{N}, 211^{\circ} \mathrm{E}$ $\left(\mathrm{dp}=12^{\circ}, \mathrm{dm}=18^{\circ}\right)$, in keeping with the coeval ages of these two granites. The post-Nyanzian Migori granite $(2739 \pm 111 \mathrm{Ma}$, Cahen et al., 1984 ) yields a paleomagnetic pole at $72^{\circ} \mathrm{N}$, $336^{\circ} \mathrm{E}\left(\mathrm{dp}=6^{\circ}, \mathrm{dm}=12^{\circ}\right.$, Patel, 1989), although this body may well have been tilted during D1 or D2. The gabbro at Garauja-Basotu (Krs et al., 1983) gives a tilt-corrected pole at $27^{\circ} \mathrm{S}, 341^{\circ} \mathrm{E}$, very close to the tilt-corrected Nyanzian pole. The Garauja gabbro pole is estimated at $2600 \mathrm{Ma}$; however, as with all dykes / mafic intrusions into the Tanzanian Craton this age is poorly constrained. The in-situ pole for the gabbro at Garauja-Basotu falls at $18^{\circ} \mathrm{N}, 348^{\circ} \mathrm{E}$. This in-situ pole lies adjacent to younger poles from the Tanzanian Craton (Kisii lavas pole, Brock et al., 1972) and away from the Nyanzian in-situ pole such that it is difficult to constrain the age of this body to within less than $300 \mathrm{Ma}$.

The Nyanzian System paleopole falls at $14^{\circ} \mathrm{N}$, $150^{\circ} \mathrm{E}\left(\mathrm{dp}=5^{\circ}, \mathrm{dm}=7^{\circ}\right)$ and is significantly different from both the post-Nyanzian granite and post-Kavirondian granite poles. The in-situ Nyanzian pole $\left(46^{\circ} \mathrm{N}, 198^{\circ} \mathrm{E}, A_{95}=15^{\circ}\right)$ does fall near the post-Kavirondian granite poles. Despite the similarity of this in-situ Nyanzian pole to the post-Kavirondian poles, we maintain that only the tilt-corrected Nyanzian pole is correct and likely results from a primary magnetization on the basis of the following arguments. The 


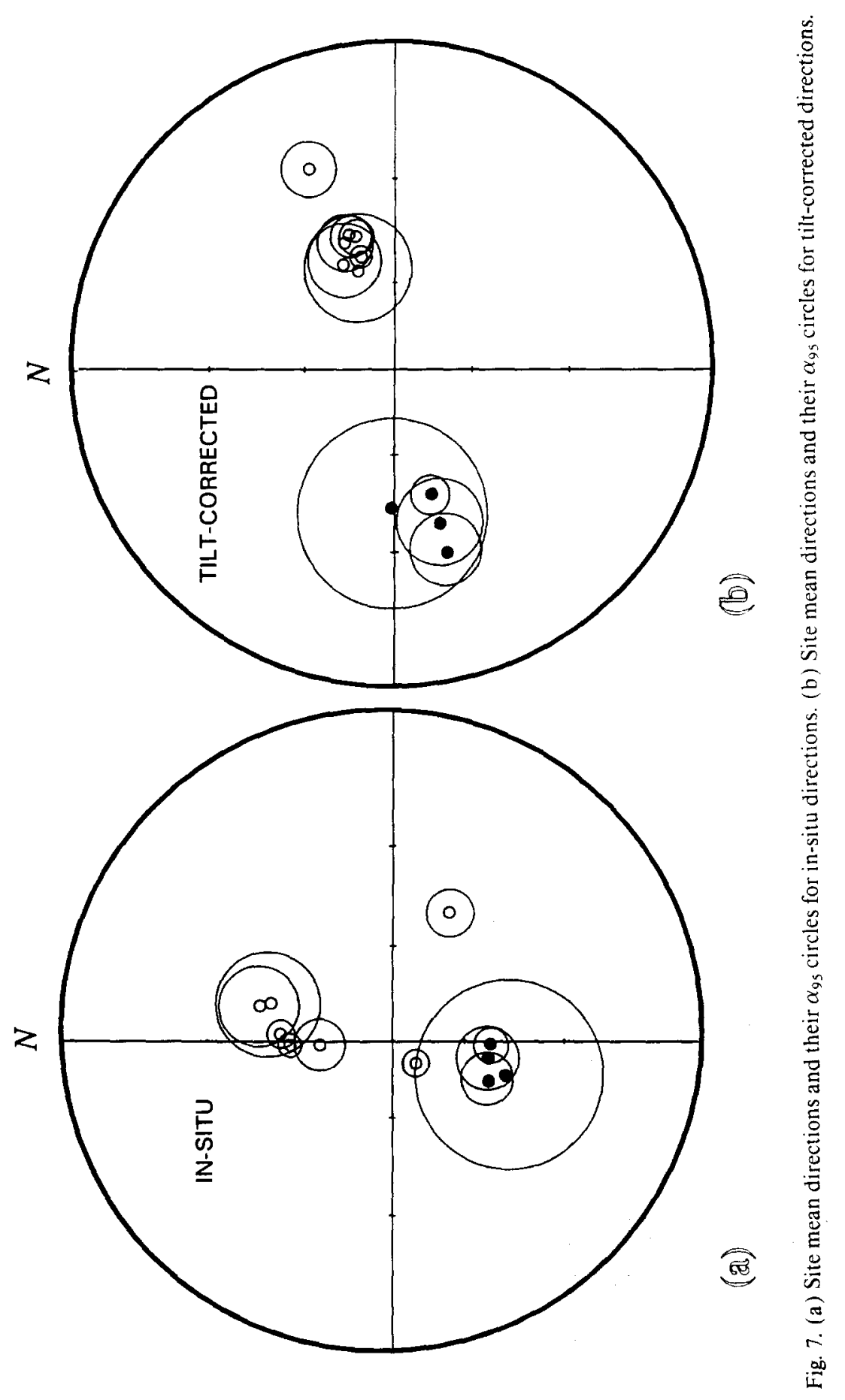



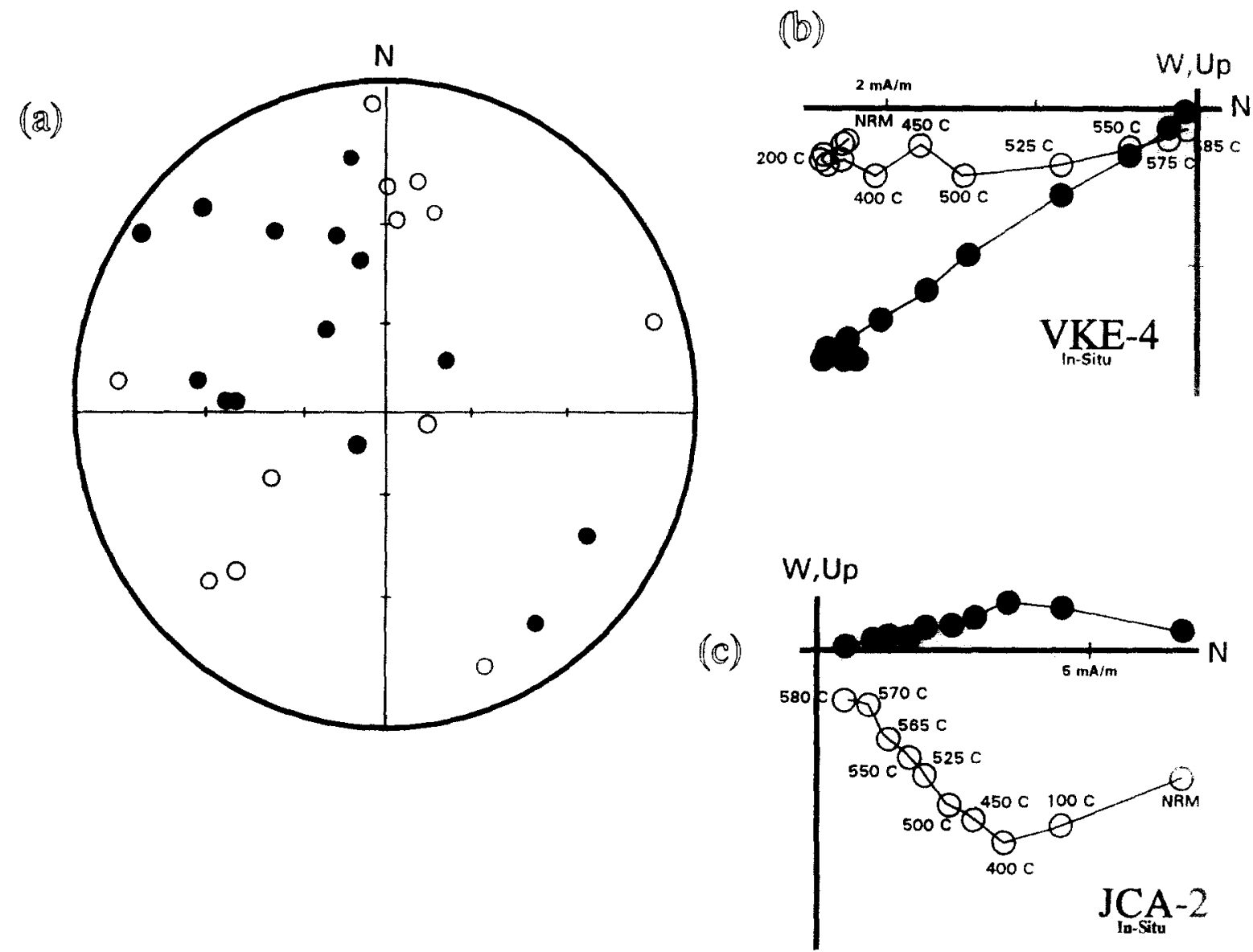

Fig. 8. (a) Stereoplot of all components isolated in clasts of Nyanzian materials found in the Kavirondian conglomerate. (b) Orthogonal vector plot of a Nyanzian basalt clast taken from the Kavirondian conglomerate at Site 7. (c) Orthogonal vector plot of a Nyanzian rhyolite clast taken from the Kavirondian conglomerate at Site 7.

Nyanzian lavas pass a fold test, conglomerate test and reversal test (tilt-corrected) which, when taken together, indicate a magnetization acquired prior to D1, Kavirondian deposition and D2 folding $(2472<\mathrm{D} 2<$ Kavirondian $<$ D1 (?) < $2739 \mathrm{Ma}<\mathrm{D} 1($ ?) $<$ Nyanzian ). The samples from the Kavirondian conglomerate were collected in the vicinity of the Wanjare granite (Site 7), yet the rocks show none of the typical penetrative deformation (shearing), nor does the calculated mean $\left(D=259^{\circ}, I=+39^{\circ}\right.$, random at $95 \%$ confidence level $)$ fall close to the Wanjare mean $\left(D=342^{\circ}, I=-46^{\circ}\right)$. Finally, the post-Nyanzian granite pole is significantly different from the post-Kavirondian poles suggest- ing that it was not reset by post-Kavirondian intrusion.

When trying to interpret Archean paleomagnetic data on a global basis a number of practical problems arise that are magnified when reviewing the African paleomagnetic data. Table 2 lists all African paleopoles that fall in the range 2000$3000 \mathrm{Ma}$ along with their "quality-factor" $Q$ ( see Van der Voo, 1990 for a complete discussion ). It is clear from this compilation that most of the African Archean-Paleoproterozoic data are of "low-quality" ( $Q$-mean $=2.5$; compare to the Phanerozoic $Q$-mean $=4.5$ for Europe and North America). The mean $Q$ of 2.5 matches the mean $Q$ reported by us for these three nuclei in the later 
Table 2

Paleomagnetic poles from Africa in the age range 2000-3000 Ma

\begin{tabular}{|c|c|c|c|c|c|c|c|}
\hline Pole name & Age range & $Q$-factor & $P_{\text {lat }}$ & $P_{\text {long }}$ & $\mathrm{dp}$ & $\mathrm{dm}$ & Reference \\
\hline \multicolumn{8}{|l|}{ Kalahari Craton } \\
\hline Palabora Igneous Complex I & $1900-2100$ & 2 & 35 & 45 & 7 & 11 & Morgan and Briden, 1981 \\
\hline Palabora Igneous Complex II & $1900-2100$ & 4 & 4 & 356 & 9 & 11 & Morgan and Briden, 1981 \\
\hline Limpopo metamorphics & $1900-2100$ & 4 & 26 & 22 & 8 & 10 & Morgan and Briden, 1981 \\
\hline Marico River & $1000-2500$ & 1 & 15 & 300 & 6 & 11 & Evans, 1967 \\
\hline Orange River lavas & $1960-2070$ & 2 & 19 & 254 & 18 & 22 & Piper, 1975 \\
\hline Bushveld main zone & $2038-2062$ & 4 & 20 & 33 & 6 & 7 & Hattingh, 1986 \\
\hline Bushveld gabbro & $2038-2062$ & 3 & 23 & 36 & 12 & 12 & $\begin{array}{l}\text { Gough and Van Niekirk, } \\
1959\end{array}$ \\
\hline Merensky reef & $2038-2062$ & 2 & 40 & 47 & 8 & 13 & Hattingh, 1986 \\
\hline Transvaal lavas & $2150-2350$ & 3 & 40 & 194 & 28 & 28 & Briden, 1976 \\
\hline Gaberones granite & $2780-2830$ & 4 & 35 & 104 & 16 & 16 & Evans, 1967 \\
\hline Modipe gabbro & $2340-2810$ & 3 & 33 & 211 & 11 & 11 & Evans and McElhinny, 1966 \\
\hline Great Dike mean & $2444-2476$ & 3 & 21 & 58 & 6 & 6 & Jones et al., 1976 \\
\hline Mbanane pluton & $2682-2692$ & 4 & 20 & 106 & 4 & 7 & Layer et al., 1989 \\
\hline Ventersdorp lavas & $2683-2915$ & 1 & 55 & 175 & 22 & 22 & Jones et al., 1967 \\
\hline Usushwana Complex & $2835-2915$ & 3 & 9 & 347 & 8 & 8 & Layer et al., 1988 \\
\hline \multicolumn{8}{|l|}{ Congo Craton } \\
\hline Cunene anorthosite & $1900-2700$ & 2 & -3 & 255 & 15 & 22 & Piper, 1974 \\
\hline Oldoinyo gneiss & $1600-2500$ & 1 & 62 & 151 & 5 & 9 & Mauritsch and Pondaga, 1985 \\
\hline Post-Kavirondian granites & $2350-2500$ & 3 & 41 & 263 & 15 & 23 & Patel, 1989 \\
\hline Garauja gabbro (TC) & $2400-2600$ & 2 & 27 & 161 & 7 & 9 & Krs et al., 1983 \\
\hline Garauja gabbro (IS) & & & -18 & 168 & 7 & 9 & Krs et al., 1983 \\
\hline Mumias granite & $2426-2526$ & 3 & 61 & 211 & 12 & 18 & Patel and Raja, 1979 \\
\hline Post-Nyanzian granites & $2600-2850$ & 2 & 72 & 336 & 6 & 12 & Patel, 1989 \\
\hline Nyanzian System lavas (TC) & $>2850$ & 5 & 14 & 150 & 5 & 7 & This study \\
\hline Nyanzian System lavas (IS) & & 4 & 46 & 198 & & & This study \\
\hline \multicolumn{8}{|l|}{ West African Craton } \\
\hline Nimba-Harper $A$ & $1892-2056$ & 3 & 18 & 269 & 16 & 21 & Onstott and Dorbor, 1987 \\
\hline Ecglab plutons $\mathrm{E}$ & $1920-2074$ & 2 & 6 & 270 & 8 & 11 & Lassere et al., 1970 \\
\hline Obuasi Dike & $2000-2200$ & 2 & 56 & 249 & 6 & 11 & Piper and Lomax, 1973 \\
\hline Tarkwa dolerite & $2000-2200$ & 2 & 53 & 216 & 11 & 17 & Piper and Lomax, 1973 \\
\hline Obuasi greenstone & $2150-2250$ & 0 & 50 & 282 & 11 & 21 & Piper and Lomax, 1973 \\
\hline
\end{tabular}

Notes. $Q$-value based on the total number of specific requirements (as set forth in Van der Voo, 1990) a particular pole meets. These requirements are: (a) well-determined age $\pm 4 \%$ or 40 Ma whichever is lower; (b) number of samples $>24$, precision parameter $k>10, \alpha_{95}<16$; (c) adequate demagnetization using vector subtraction or principal component analysis; (d) field tests such as fold, contact and conglomerates; (e) structural control; (f) presence of reversals; and (g) no suspicion of remagnetization. For a more detailed discussion see Van der Voo, 1990. TC=tilt-corrected; IS=in-situ.

Proterozoic (Van der Voo and Meert, 1991). In that paper we concluded that reconstructions involving the cratonic nuclei of Africa were untestable for the time period 1100-550 Ma given the low $Q$ and, perhaps more significantly, the lack of well-defined ages for the more reliable paleomagnetic poles. These same problems exist for the Archean-Paleoproterozoic data from Africa given in Table 2. There are, however, several welldated poles that allow "spot-readings" of the relative positions of the Tanzanian and Kaapvaal/ Zimbabwe Cratons. Fig. 9 shows all the paleomagnetic poles $(Q \geqslant 2)$ determined on rocks in the Tanzanian Craton and the associated errors $(\mathrm{dp}, \mathrm{dm})$ along with the four well-dated poles from the Kaapvaal/Zimbabwe Craton that 


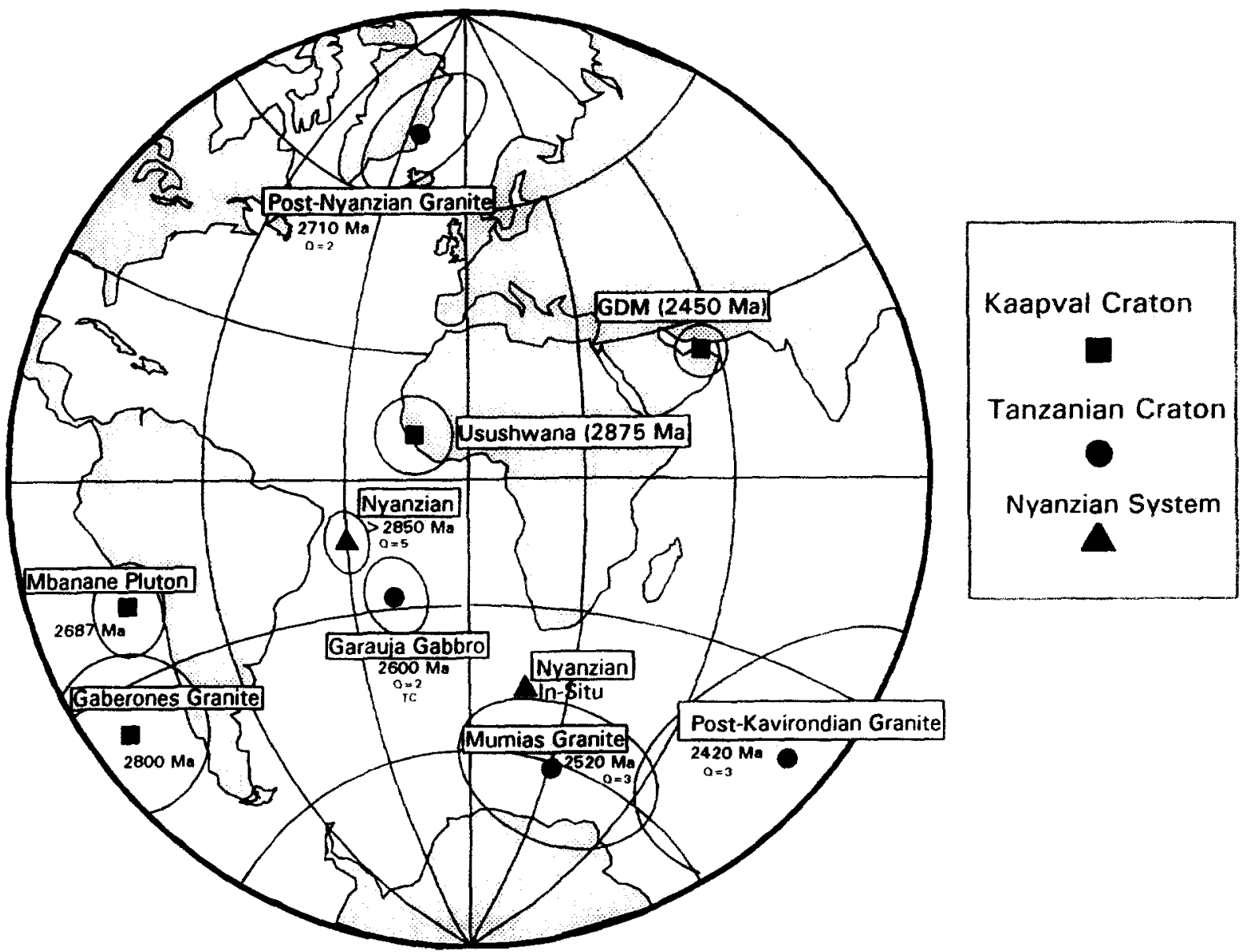

Fig. 9. Plot of all paleomagnetic poles from the Tanzanian Craton $(Q \geqslant 2)$ with their error ellipses and four of the more reliable paleomagnetic poles from the Kaapvaal Craton which have concordant ages with the Tanzanian Craton poles (some poles are inverted for convenience in plotting)

match the time periods of well-dated poles from the Tanzanian Craton. The West African data set is, at present, too meager and of the wrong age range for viable testing of relative positions.

It is practically impossible to construct any sort of apparent polar wander path (APWP) for either craton since the time gap between successive poles is on the order of $100 \mathrm{Ma}$. Nevertheless, comparisons between individual poles suggest that it is more likely that the Tanzanian and Kaapvaal/Zimbabwe Cratons moved independently during the time period from 2875 to 2420 $\mathrm{Ma}$ than that they drifted together in the same relative position as today's. The Nyanzian (tiltcorrected pole) is constrained to be older than $\sim 2850 \mathrm{Ma}$ by intrusive relationships (Dodson et al., 1975; Cahen et al., 1984) and positive field tests (e.g. conglomerate and fold tests). The age constraints placed on the Nyanzian greenstone belt place it close to the age of the Usushwana Complex (2875 Ma) and the Gaberones granite $(2800 \mathrm{Ma})$. The paleomagnetic poles for the Nyanzian System and the two poles from the Kaapvaal Craton are more than $28^{\circ}$ apart and their error ellipses do not overlap. If the age of the Nyanzian System is indeed close to the estimates provided by several authors (Cahen et al., 1984), then the paleopoles imply that these two cratons were drifting independently at that time (2800$2875 \mathrm{Ma}$ ). Similarly, the Mbanane pluton (2686 
Ma) and the post-Nyanzian granites $(2710 \mathrm{Ma})$ poles are $80^{\circ}$ apart suggesting that the cratons continued to drift independently. Finally we note that the Great Dike mean result $(2450 \mathrm{Ma})$ lies some $75^{\circ}$ away from similar age poles in the Tanzanian Craton (Mumias granite and postKavirondian granites mean pole at $54^{\circ} \mathrm{N}$, $243^{\circ} \mathrm{E}$ ). While there are certainly some problems with the preceding interpretation (mainly uncertainty in the exact age of the Nyanzian System) it is evident that any supercontinent hypothesis (e.g. Piper, 1987) fails to explain the disparity of paleomagnetic results from these two nuclei. The best that can be said about such reconstructions is that the lack of a high-quality African data base for the time period of 2000 3000 Ma precludes a resolution about Africa's tectonic evolution at this time.

\section{Conclusions}

The Nyanzian System lavas ( $>2850 \mathrm{Ma}$ ) yield a tilt-corrected pole at $14^{\circ} \mathrm{N}, 150^{\circ} \mathrm{E}\left(\mathrm{dp}=5^{\circ}\right.$, $\mathrm{dm}=7^{\circ}$ ) that passes a fold, conglomerate and reversal test (tilt-corrected) indicating the Archean (and likely) primary nature of this magnetization. The compiled paleomagnetic data base for the three cratonic nuclei that constitute the core of the present-day African continent (Congo, Kaapvaal/Zimbabwe and West Africa) are, at present, of insufficiently high quality to allow construction of meaningful apparent polar wander paths or the testing of long-lived supercontinent models. Two of the cratons (Tanzanian and Kaapvaal/Zimbabwe) do have several well-dated poles of similar age which allows limited testing of cratonic coherence for these two nuclei. The similar age poles for these nuclei demonstrate (albeit in preliminary fashion) that the Tanzanian and Kaapvaal/Zimbabwe Cratons were drifting independently at $\sim 2850 \mathrm{Ma}$, $\sim 2700 \mathrm{Ma}$ and $\sim 2500 \mathrm{Ma}$. On the basis of these conclusions, the supercontinent model of Piper (1987) can no longer involve a coherent African continent for the time period from 2900 to 2500 Ma.

\section{Acknowledgements}

We gratefully acknowledge Gareth Davies for his assistance in the field and Andy Nyblade for reviewing an early version of this manuscript. We also wish to thank Tullis Onstott, S.A. Elming and an anonymous reviewer for helpful suggestions on the manuscript. The argon work was accomplished with the able assitance of Marcus Johnson and Chris Hall who also reviewed the appendix to this paper. The authors wish to thank the following organizations for their financial support of this project: Government of Kenya, Kenya Division of Mines and Geology; Sigma Xi, Geological Society of America and the University of Michigan Department of Geological Sciences Scott Turner Fund. Research supported by the Division of Earth Sciences, National Science Foundation grant EAR 92-05815.

\section{Appendix-Age of the Nyanzian pole}

The original paper for the Nyanzian rocks was written prior to the acquisition of ${ }^{40} \mathrm{Ar} /{ }^{39} \mathrm{Ar}$ data from the Nyanzian basalts. We report herein the results of those studies that constrain the age of the Nyanzian pole and allow us to make a more definitive test of the relationship between the Congo (Tanzanian) and Kaapvaal cratons in the Late Archean.

\section{${ }^{40} \mathrm{Ar} /{ }^{39} \mathrm{Ar}$ results}

Samples of Nyanzian basalt were collected from Sites 11 and 14 (see map in original paper) for age determination. These basalts are very fine-grained; however, a few samples contained hornblendes as replacement minerals that were in the size range $100-125 \mu \mathrm{m}$. These hornblendes were separated, purified and irradiated at the University of Michigan's Ford-Phoenix Reactor. Following irradiation, the samples were stepwise treated using an Ar-laser system and the argon isotopic ratios (40-36) were measured on a MAP-215 mass spectrometer operating in static mode. Neutron flux gradients were monitored with MMhb-1 (Alexander et al., 1978) using an age of 520.4 Ma. Samples consisted of 4-5 grains of hornblende during the initial runs and single grain replicates were outgassed in three steps to determine any grain-to-grain variability. Analytical data for three samples are given in Table A-1.

Fig. A-1 shows typical stepwise outgassing spectra for samples from site 11 (Fig. A-1 a) and Site 14 (Figs. A-1c,A-1e) along with their associated $\mathrm{Ca} / \mathrm{K}$ ratios. Plateau ages $T_{\mathrm{p}}$ were determined when $\geq 50 \%$ of the gas was released over two suc- 
Table A-1

Analytical data for three samples

\begin{tabular}{|c|c|c|c|c|}
\hline${ }^{40} \mathrm{Ar} /{ }^{39} \mathrm{Ar}$ & ${ }^{37} \mathrm{Ca} /{ }^{39} \mathrm{~K}$ & \%Total ${ }^{39} \mathrm{Ar}$ & \%Atmos & Apparent age \\
\hline \multicolumn{5}{|c|}{ Sample $11-1$, hornblende, $J=7.41541 \times 10^{-3}$} \\
\hline $1.26888 \times 10^{+2}$ & 2.95185 & 1.61 & 60.41 & $1196 \pm 113$ \\
\hline $2.63092 \times 10^{+2}$ & 9.26134 & 1.37 & 33.84 & $1952 \pm 163$ \\
\hline $3.87957 \times 10^{+2}$ & 9.30909 & 18.91 & 1.97 & $2444 \pm 19$ \\
\hline $4.53156 \times 10^{+2}$ & 9.56099 & 53.01 & 0.77 & $2657 \pm 10$ \\
\hline $4.63750 \times 10^{+2}$ & 11.74260 & 25.10 & 1.77 & $2689 \pm 10$ \\
\hline
\end{tabular}

Total gas age $2601 \pm 16$; Plateau age $2672 \pm 32 \mathrm{Ma}$

Sample 14-1, hornblende, $J=7.47571 \times 10^{-3}$

\begin{tabular}{|c|c|c|c|c|}
\hline $8.11622 \times 10$ & 2.70538 & 2.07 & 52.90 & $850 \pm 22$ \\
\hline $1.28411 \times 10^{+2}$ & 6.53701 & 1.82 & 25.42 & $1206 \pm 23$ \\
\hline $3.93446 \times 10^{+2}$ & 10.9914 & 5.29 & 1.96 & $2463 \pm 18$ \\
\hline $4.52970 \times 10^{+2}$ & 9.67883 & 16.73 & 0.58 & $2656 \pm 09$ \\
\hline $4.55498 \times 10^{+2}$ & 9.14881 & 36.71 & 0.39 & $2663 \pm 05$ \\
\hline $4.61690 \times 10^{+2}$ & 9.27706 & 3.44 & 0.97 & $2682 \pm 14$ \\
\hline $4.63125 \times 10^{+2}$ & 9.06297 & 12.84 & 0.54 & $2686 \pm 10$ \\
\hline $4.62282 \times 10^{+2}$ & 10.0897 & 4.19 & 1.15 & $2684+13$ \\
\hline $4.60728 \times 10^{+2}$ & 11.0703 & 16.91 & 1.30 & $2679+07$ \\
\hline
\end{tabular}

Total gas age $2617 \pm 8$; Plateau age $2670 \pm 10 \mathrm{Ma}$

Sample 14-2, hornblende, $J=7.47571 \times 10^{-3}$

$\begin{array}{lcr}8.96652 \times 10 & 4.76266 & 2.89 \\ 2.96697 \times 10^{+2} & 10.2924 & 3.64 \\ 4.53359 \times 10^{+2} & 9.41532 & 33.12 \\ 4.52224 \times 10^{+2} & 9.20509 & 9.65 \\ 4.60385 \times 10^{+2} & 9.08253 & 9.26 \\ 4.62659 \times 10^{+2} & 10.0775 & 23.51 \\ 4.60501 \times 10^{+2} & 11.0743 & 17.93\end{array}$

$\begin{array}{rr}47.11 & 919 \pm 20 \\ 4.35 & 2099 \pm 20 \\ 0.50 & 2657 \pm 03 \\ 0.87 & 2654 \pm 11 \\ 0.79 & 2678 \pm 13 \\ 0.47 & 2685 \pm 04 \\ 1.37 & 2678 \pm 07\end{array}$

Total gas age $2619 \pm 7$; plateau age $2683 \pm 4 \mathrm{Ma}$

Apparent age errors are reported as $1 \sigma$. All other errors are reported as $2 \sigma$. Errors associated with the irradiation parameter $J$ are less than $0.5 \%$.

cessive steps with overlapping ages (using $2 \sigma$ errors; all errors reported here are $2 \sigma$ ). Preferred ages $T_{\mathrm{pf}}$ are used when less than $50 \%$ of the gas was released with overlapping ages. Total gas ages are given in Table A-1. Platteau ages are $2672 \pm 32 \mathrm{Ma}$ for sample 11-1, 2670 $\pm 10 \mathrm{Ma}$ for sample 141 (split 1 ) and 2683 \pm 4 Ma for sample 14-1 (split 2). Replicates of samples from Site 11 show large variability and failed to yield plateau ages although the more radiogenic release ages are compatible with the above results $(2678 \pm 15 \mathrm{Ma}$ over $20 \%$ of the gas) and one sample yielded an isochron age of $2696 \pm 14 \mathrm{Ma}$ (MSWD $=1.11$ ). A single-grain replicate from Site 14 gave an age of $2670 \pm 24 \mathrm{Ma}$ over $51 \%$ of the gas. We also note that samples 11-1 (Fig. A-1a) and 14-1 (Fig. A-1c) show ages $\left(T_{\mathrm{pf}}\right)$ of $2689 \pm 20 \mathrm{Ma}$ and $2682 \pm 4 \mathrm{Ma}$, respectively, over their final release stteps. Collectively, we con- sider these ages to indicate an age between 2670 and 2690 Ma for the Nyanzian pole.

\section{Discussion}

Coomer and Robertson (1974) conducted $\mathrm{Pb}-\mathrm{Pb}$ studies on sulfides formed during mineralization associated with the intrusion of the Migori granite into the Nyanzian basalt and determined an age of $2700 \pm 150 \mathrm{Ma}$. Yanagi and Suwa (1981) computed a Rb-Sr whole-rock age for the Nyanzian basalts of $2710 \pm 340 \mathrm{Ma}$. The Migori granite was dated at $2739 \pm 111 \mathrm{Ma}$ by Dodson et al. (1975). These ages are broadly coeval with out ${ }^{40} \mathrm{Ar} /{ }^{39} \mathrm{Ar}$ ages and suggest that the hornblendes formed during hydrothermal alteration of the Nyanzian System associated with the intrusion of the Migori 

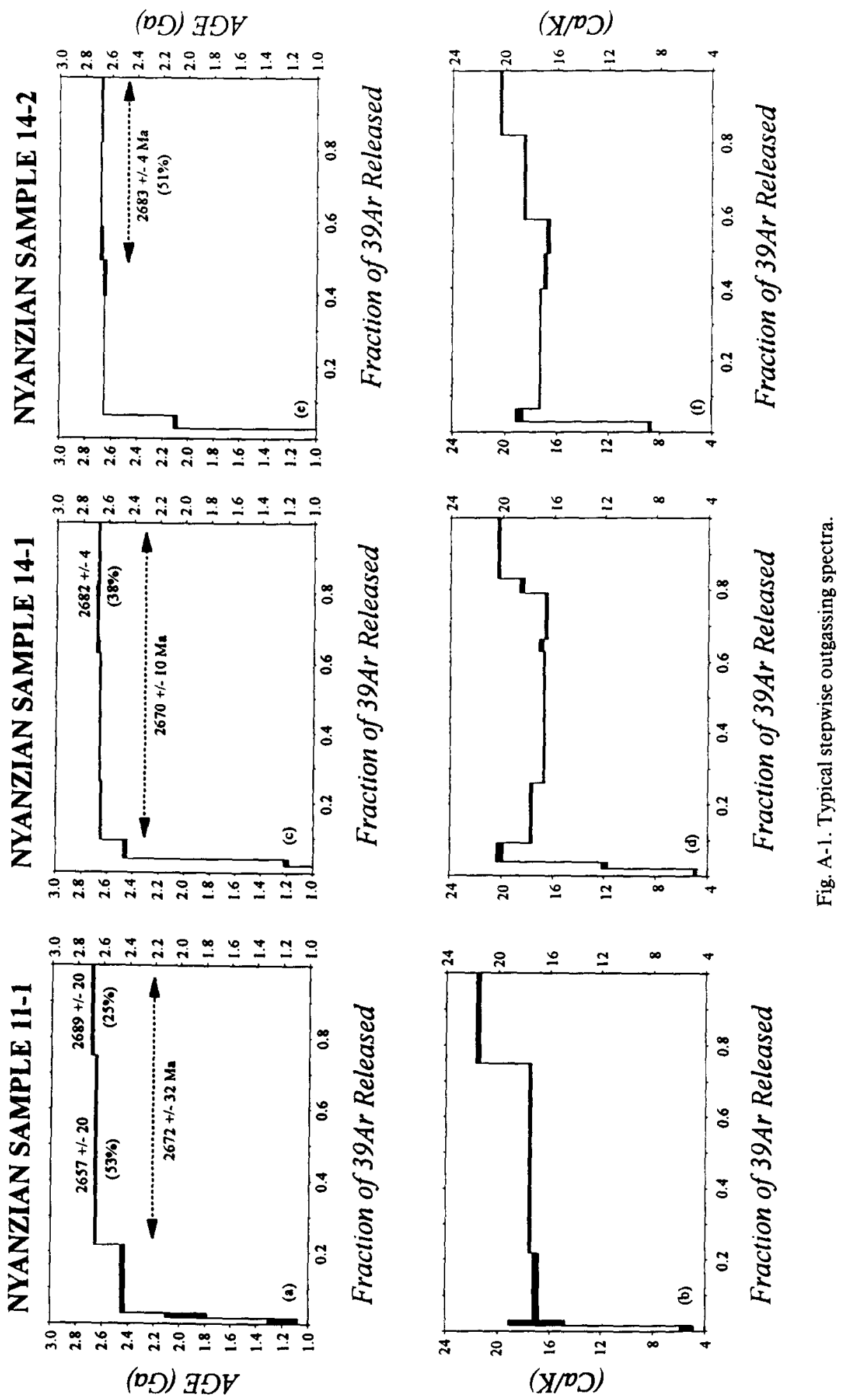
granites. This alteration chemically reset the original magnetization in the Nyanzian rocks and the age of $2670-2690$ Ma for the Nyanzian rocks is considered to date the remagnetization. Field tests constrain the age of the paleomagnetic pole to be older than D1 and the Kavirondian conglomerate ( $\geq 2470 \mathrm{Ma}$, see text). Since boulders of the Migori granite are found in the Kavirondian conglomerate we consider D1 to be younger than the intrusion of the Migori granite but older than the Kavirondian conglomerate. Therefore, DI is older than 2470 but younger than $2690 \mathrm{Ma}$. Because the D1 is younger than the Migori granite the post-Nyanzian granites pole (Patel, 1989; see Table 2) is no longer considered to accurately reflect the position of the Tanzanian craton because it was tilted during subsequent deformation.

The Mbanane pluton pole reported by Layer et al. (1989; see Table 2) has an age of $2685 \pm 5 \mathrm{Ma}$ allowing for an approximate comparison between the paleopositions of the Congo (Tanzanian) and Kaapvaal cratons. The ages of the Mbanane pole and the Nyanzian pole roughly overlap after recalibration of the Nyanzian ages to the 3gr-standard used by Layer et al. (1989). This results in a slightly lower age estimate for the Nyanzian between 2650 and $2670 \mathrm{Ma}$. The poles for these two cratons are 42 apart (see Fig. 9), although the paleolatitudinal separation between the two cratons is similar to the present-day separation. Thus, we cannot conclusively state that the two cratons were drifting independently during this interval, based on these paleomagnetic data. We do note that a reconstruction such as that used by Piper (1987) requires coeval poles to fall in the same location. This criterion is not met by our data.

\section{References}

Alexander, E.C., Jr., Michelson, G.M. and Lanphere, M.A. 1978. MMhb-1: a new ${ }^{40} \mathrm{Ar} /{ }^{39} \mathrm{Ar}$ dating standard. In: R.E. Zartman (Editor), Short Papers of the 4th International Conference, Geochronology, Cosmochronology, Isotope Geology. U.S. Geol. Surv. Open-File Rep., 78-701 : 6-8

Bell, K. and Dodson, M.H., 1981. The geochronology of the Tanzanian Shield. J. Geol., 89: 109-128.

Briden, J.C., 1976. Paleomagnetic investigation of the Transvaal system lavas, South Africa. Philos. Trans. R. Soc. London, A280: 405-416.

Brock, A., Raja, P. and Vise, J., 1972. Paleomagnetism of the Kisii Series, western Kenya. Geophys. J. R. Astron. Soc., 28: $129-137$

Cahen, L., Snelling, N.J., Delhal, J. and Vail, J.R., 1984. The Geochronology of Equatorial Africa. North Holland, Amsterdam, $454 \mathrm{pp}$.

Clifford, T.N., 1971. The structural framework of Africa. In: T. Clifford and I. Gass (Editors), African Magmatism and Tectonics. Oliver and Boyd, Edinburgh, pp. 1-26.

Coomer, P.G. and Robertson, D.K., 1974. Common lead isotope study of Archean mineralized areas in Tanzania. Geol. Soc. London, 130: 449-460.
Davis, P.A. and Condie, K.C. 1977. Trace element model studies of Nyanzian greenstone belts, western Kenya Geochim. Cosmochim. Acta, 41:271-27?

Dodson, M.H., Gledhill, A.R., Shackleton, R.M. and Bell, K. 1975. Age differences between Archean cratons of Eastern and Southern Africa. Nature, 254: 315-318.

Evans, M.E., 1967. A paleomagnetic study of the Gaberones granite of Botswana. Geophys. J. R. Astron. Soc. 19,49 498.

Evans, M.E. and McElhinny, M.W., 1966. The paleomagnetism of the Modipe Gabbro. J. Geophys. Res. 776053 6064.

Fisher, R.A., 1953. Dispersion on a sphere. Proc K. Soo London, A217: 295-305.

Gough, D.I. and Van Niekirk, A., 1959. A study of the paleomagnetism of the Bushveld Gabbro. Philos. Mag. 4:126136.

Grantham, D.R., 1945. Explanation of the geology of degree sheet no. 17 (Kahama). Geol. Surv, Dep. Land Mines. Tanganyika, Rep. 15.

Hale, C.J., 1991. Towards an Archean apparent polar wander path. 5th NE Paleomagnetic and Rock Magnetic Workshop, Program and Abstracts, Abstr. 24.

Hattingh, P.J., 1986. The paleomagnetism of the main zont in the western Bushveld Complex. Earth Planet. Sci. Leth. 79: 441-452.

Huddleston, A., 1951. Geology of the Kisii District Gow Printing Office, Kenya Geological Survey, $65 \mathrm{pp}$.

Ichang'i, D.W. and MacLean, W.H., 1991. The Archean vol canic facies in the Migori segment, Nyanza greenstone belt Kenya: stratigraphy, geochemistry and mineralization. $j$ Afr. Earth Sci., 13: 277-290.

Irving, E., 1964. Paleomagnetism and its Application to Geo logical and Geophysical Problems. Wiley, New York. N.Y. 399 pp.

Johnson, H.P., Lowrie, W. and Kent, D. V.. 1975. Stability of anhysteretic remanent magnetization in fine and coarse magnetite and maghemite particles. Geophys. I. R. As. tron. Soc., 41: 1-10.

Jones, D.L. and McElhinny, M.W., 1967. Stratigraphic interpretation of paleomagnetic measurements on the Water berg Red Beds of South Africa. J. Geophys. Res., 72.4171 4179 .

Jones, D.L., Robertson, 1.D.M. and McFadden, P.F. 1976 A paleomagnetic study of Precambrian dike swams as sociated with the Great Dike of Rhodesia. Trans. Geol Soc. S. Afr., 78: 57-65.

Kirschvink, J.L., 1980. The least squares line and plane and the analysis of paleomagnetic data. Geophys. J. R. As tron. Soc., 62: 699-718.

Krs, M., Krsova, M., Pankka, H. and Pondaga, M.M. 1983. Paleomagnetic, petromagnetic and paleotectonic invest 1gations of Proterozoic gabbro body Garauja-Basoti. N Tanzania. Geofys. Sbornik, 20: 9-45.

Lasserre, M., Lameyre, J. and Buffiere, J.M., 1970. Donnees géochronologiques sur l'axe Précambrien Yetti Ecglab en 
Algérie et en Mauritanie du Nord. Bull. Bur. Rech. Geol. Min. Paris, 2: 5-13.

Layer, P.W., Kröner, A., McWilliams, M. and Burghele, A., 1988. Paleomagnetism and age of the Archean Usushwana Complex, southern Africa. J. Geophys. Res., 93: 449-458.

Layer, P.W., Kröner, A., McWilliams, M. and York, D., 1989. Elements of the Archean thermal history and apparent polar wander of the eastern Kaapvaal Craton, Swaziland, from single-grain dating and paleomagnetism. Earth Planet. Sci. Lett., 93: 23-34.

Mauritsch, H.J. and Pondaga, M.M., 1985. Paleomagnetic investigations on the East African Rift in northern Tanzania. J. Geodyn., 2: 265-274.

McElhinny, M.W., 1964. Statistical significance of the fold test in paleomagnetism. Geophys. J. R. Astron. Soc., 8: 338-340.

McFadden, P., 1990. A new fold test for paleomagnetism. Geophys. J. Int., 103: 163-169.

McFadden, P. and McElhinny, M.W., 1990. Classification of the reversal test in paleomagnetism. Geophys. J. Int., 103: $725-729$.

Morgan, G.E. and Briden, J.C., 1981. Aspects of Precambrian paleomagnetism with new data from the Limpopo mobile belt and Kaapvaal craton in South Africa. Phys. Earth Planet. Inter., 24: 142-168.

Onstott, T.C. and Dorbor, J., 1987. ${ }^{40} \mathrm{Ar} /{ }^{39} \mathrm{Ar}$ and paleomagnetic results from Liberia and the Precambrian APW data base for the West African Shield. J. Afr. Earth Sci., 6: 537552.

Patel, J.P., 1989. Paleomagnetic results from late Archean and Early Proterozoic granites from southwestern Kenya. J. Afr. Earth Sci., 9: 97-100.

Patel, J.P. and Raja, P.K.S., 1979. A paleomagnetic study of lower Proterozoic granites from western Kenya. Geophys. J. R. Astron. Soc., 58: 279-286.

Piper, J.D.A., 1974. Magnetic properties of the Cunene anorthosite complex, Angola. Phys. Earth Planet. Inter., 9: 353-363

Piper, J.D.A., 1975. Paleomagnetic correlations of Precambrian formations of east-Central Africa and their tectonic implications. Tectonophysics, 26: 135-161.
Piper, J.D.A., 1987. Paleomagnetism and the Continental Crust. Wiley, New York, N.Y., 434 pp.

Piper, J.D.A. and Lomax, K., 1973. Paleomagnetism of Precambrian Birrimian and Tarkwaian rocks of West Africa. Geophys. J. R. Astron. Soc., 34: 435-450.

Pulfrey, W., 1945. Geological survey of Maramma and adjoining areas, Western Kakamega Kavirondo. Report 8, Mining Geol. Dept. Kenya.

Quennell, A.M., 1956. Summary of the geology of Tanganyika. Mem. Geol. Surv. Tanganyika, 1.

Rumvegeri, B.T., 1991. Tectonic significance of Kibaran structures in Central and Eastern Africa. J. Afr. Earth Sci., 13: $267-276$.

Saggerson, E.P., 1952. Geology of the Kisumu District: Degree Sheet 41, N.E. quadrant. Rep. Geol. Surv. Kenya, 21, $86 \mathrm{pp}$.

Sanders, L.D., 1965. Geology of the contact between the Nyanza Shield and the Mozambique Belt in western Kenya. Bull. Geol. Surv., Kenya Rep. 7.

Shackleton, R.M., 1946. Geology of the Migori gold belt and adjoining areas. Bull. Geol. Surv., Kenya Rep. 10.

Symons, D.T.A., 1991. Paleomagnetism of the Wathonian batholith-the suture demarcating the destruction of the Proterozoic Manikewan Ocean in the Trans-Hudson Orogen, Canada. 5th NE Paleomagnetic and Rock Magnetic Workshop, Program and Abstracts, 33.

Van der Voo, R., 1990. The reliability of paleomagnetic data. Tectonophysics, 184: 1-9.

Van der Voo, R. and Meert, J.G., 1991. Late Proterozoic paleomagnetism and tectonic models: a critical appraisal. Precambrian Res., 53: 149-163.

Wendt, I., Besang, C., Harre, W., Kreuzer, H., Lenz, H. and Muller, P., 1972. Age determinations of granitic intrusions and metamorphic events in the early Precambrian of Tanzania. 24th Int. Geol. Congr., Sect. 1, p. 314.

Yanagi, T. and Suwa, S., 1981. Rb-Sr radiometric dating on Precambrian rocks in the western part of Kenya. 6th Prelim. Rep. African Studies, Nagoya Univ., pp. 163-172.

Zijderveld, J.D.A., 1967. A.C. demagnetization of rocks: analysis of results. In: D.W. Collinson, K.M. Creer and S.K. Collinson (Editors), Methods in Paleomagnetism. Elsevier, Amsterdam, pp. 254-286. 